Caderno Seminal Digital

Caderno Seminal Digital

\title{
A PLURALIDADE SÍGNICA DAS PLATAFORMAS DIGITAIS E A MUDANÇA DAS FORMAS DE PRODUÇÃO E RECEPÇÃO DA INFORMAÇÃO NO WEBJORNALISMO
}

THE PLURALITY SIGNIC OF DIGITAL PLATFORMS AND CHANGE OF PRODUCTION AND RECEPTION FORMS OF THE INFORMATION ON WEBJOURNALISM

Diego Braga Toledano Claudio Manoel de Carvalho Correia

UFAM

Resumo: Este trabalho tem como objetivo observar como as plataformas digitais influenciam as formas e os meios pelos quais as notícias e as informações são propagadas, modificando os níveis cognitivos de recepção da informação nas redações jornalísticas, na medida em que o uso de dispositivos portáteis propiciam novas possibilidades e potencialidades de visualização da notícia em diferentes linguagens nas plataformas digitais. A linguagem hipermidiática que emerge no ciberespaço possui a natureza de diferentes signos e linguagens, exigindo uma leitura semiótica das informações por meio da integração de fotos, vídeos e textos, ou seja, a partir da união de ferramentas hipermidiáticas que equilibram os níveis da informação das mídias. Assim, este estudo irá observar a participação das plataformas digitais na propagação da informação e as formas como estas plataformas, constituídas por diferentes signos e linguagens, podem modificar a prática jornalística e as formas de recepção da notícia.

Palavras-chave: Plataformas digitais, linguagens, informação, webjornalismo.

Abstract: This research aims to observe how the digital platforms influence the ways and the means through which news and information are disseminated, changing the cognitive levels of reception in news companies, at the same time as the portable devices propitiate new possibilities of visualization of news in different languages on the digital

Caderno Seminal Digital Ano 19, no 19, V. 19 (Jan-Jun/2013) - ISSN 1806-9142

92

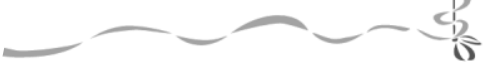


Caderno Seminal Digital

id

platforms. A hypermediatic language that emerges from the cyberspace has the nature of different signs and languages, demanding a semiotical reading of information through the integration of photos, videos and texts. In other words, read information through the gathering of hypermediatic tools that balance the levels of information of medias. Therefore, this study will observe the participation of digital platforms during the propagation of information and the ways that these platforms, constructed by different signs and languages, can modify the practice of Journalism and the reception forms of news.

Keywords: digital platforms, languages, information, web journalism

\section{INTRODUÇÃO}

Após o "boom" da Internet, durante o período de 1995 a 2000, e com o desenvolvimento posterior de ferramentas para a rede mundial de computadores, chegou um momento em que o receptor de uma mensagem passou da função de ouvir quietamente o monólogo da imprensa, ou esperar por semanas para dar um feedback da notícia, diretamente para a possibilidade de diálogo imediato entre agentes que revezam os papéis dentro do sistema de comunicação. Esta pesquisa ${ }^{20}$ tem como objetivo buscar respostas para as formas como as plataformas digitais influenciam as formas e os meios pelos quais as notícias são propagadas e, consequentemente

\footnotetext{
${ }^{20}$ Este trabalho é parte do projeto de Iniciação Científica intitulado “Observações sobre o uso das plataformas digitais portáteis e sua influência nos níveis de recepção da informação", PIBIC-CNPq, cadastrado no Departamento de Apoio á Pesquisa da Universidade Federal do Amazonas - DAP/UFAM.
}

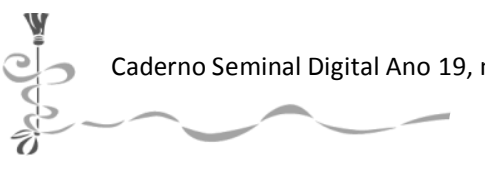

93

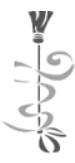


Caderno Seminal Digital

î.

apreendidas e selecionadas por profissionais da área de Jornalismo.

\section{1- TECNOLOGIA E INFORMAÇÃO: QUESTÕES CENTRAIS PARA O ENTENDIMENTO DAS NOVAS FORMAS DE PRODUÇÃO DA NOTÍCIA EM AMBIENTES DIGITAIS}

A disseminação das informações jornalísticas corrobora a teoria de Castells (1996) que diferencia as definições entre os termos "informação" e "informacional". A primeira definição, segundo o pesquisador, sempre existiu; já a segunda, devido aos avanços tecnológicos que a acionam, é fator central para a produtividade econômica, de forma que quem tem acesso à informação inicia um processo de desenvolvimento de poder. Inspiradas na teoria de Castells, Santaella e Lemos (2010, p. 16) listaram as características de uma sociedade em rede baseada nos valores informacionais de Castells, dos quais o quarto item se destaca por estar ligado às funcionalidades das Redes Sociais na Internet ( $\left.\mathrm{RCl}^{\prime} \mathrm{s}\right)$ : "cultura da virtualidade real, construída por um sistema pervasivo, interconectado e diversificado de sistemas de mídia".

Santaella e Lemos (2010) dissertam ainda sobre um sistema aberto no qual as partes integrantes são interdependentes, de forma que inputs (recebimento) e outputs (emissão) de informação influenciam o meio exterior. Além disso, tais sistemas possuem caráter autorregulatório e controle, tendo em vista a manutenção de seu equilíbrio.

Caderno Seminal Digital Ano 19, no 19, V. 19 (Jan-Jun/2013) - ISSN 1806-9142
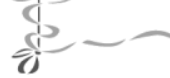
Podemos, assim, notar como tais sistemas abertos e como as definições desenvolvidas por Castells (1996) sobre informação e informacional nos levam ao meio digital portátil, no qual a informação é difundida via plataformas digitais criadas pelo desenvolvimento tecnológico e enriquecidas pela possibilidade de acesso mais rápido à informação. $\mathrm{RCl}^{\prime}$ s como Twitter, Facebook e Google+ levam-nos a repensar as formas de produção da notícia.

O modelo de comunicação proposto por Lasswell (1957) sugeria a fixação dos papéis de produtor e de receptor de códigos; porém, Wiener (1950) alerta para o fato de que deve haver o equilíbrio entre a recepção e o processamento da informação do output sobre o sistema para que haja um feedback e, posteriormente, a entrada da informação no sistema para que este corrija os erros de informação primeiramente emitida, função que configura a atividade exercida de publicação de notícias nas RCl's.

O conceito de inputs e outputs analisado por Santaella (2010) aproxima-se em muito das teorias desenvolvidas por Canavilhas (2001), cujo foco está na questão dos processos de interatividade propiciados pela Internet. Segundo a autora, há a criação de discussões entre os subsistemas da população e da imprensa para o balanceamento energético no grande sistema aberto chamado "Internet" por meio da possibilidade de diálogos igualmente ativos entre as duas partes; subsistemas estes englobados em um Rizoma, conceito

Caderno Seminal Digital Ano 19, no 19, V. 19 (Jan-Jun/2013) - ISSN 1806-9142
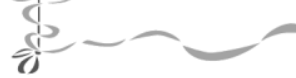

95

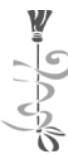


desenvolvido por Deleuze (1993). Rizomas são universos sem limites definidos; o rizoma não é uma forma, mas condição de existência das formas. É o meio do qual as formas emergem, misturando o que aparentemente era distinto e o que estava anteriormente separado. Kastrup (2009) define que qualquer ponto de um rizoma está conectado a qualquer outro. 0 rizoma conecta-se por contágio mútuo ou aliança, e cresce para todos os lados, em todas as direções. A informação é compartilhada de forma bastante semelhante nas $\mathrm{RCl}^{\prime}$, alcançando, dessa forma, diversos destinatários.

\section{2- O PROCESSO DE SEMIOSE E A PLURALIDADE SEMIÓTICA DAS NOTÍCIAS NA HIPERMÍDIA}

Vivemos em um mundo no qual somos constantemente bombarbeados por sistemas de linguagens. Porém, com o advento da hipermídia, as informações fragmentadas em signos de diferentes naturezas estão corporificadas em informações nas redes sociais. Como o profissional de Jornalismo seleciona o material para publicação em meio aos diferentes códigos e linguagens em jogo na hipermídia? Kastrup (1997) refere-se ainda à identificação de signos, palavras ou imagens, para a diferenciação do conteúdo, chamado por ela de "heterogeneidade". Segundo a autora, os braços dos rizomas não estão necessariamente ligados a um traço linguístico único, mas conecta-se a diversos modos de codificação. Porém, como se dá o processo de interpretação e de

Caderno Seminal Digital Ano 19, no 19, V. 19 (Jan-Jun/2013) - ISSN 1806-9142
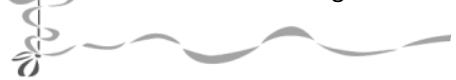

96

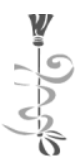


decodificação dos sistemas de signos de diferentes naturezas em jogo na hipermídia? Os signos linguísticos misturam-se aos signos visuais e sonoros gerando uma nova forma de linguagem híbrida, cujos signos de diferentes naturezas estão mesclados na geração dos sentidos e das informações. Um caminho proposto por Correia (2012, p.91-121) para o entendimento dos processos de interpretação dos signos de diferentes naturezas em sistemas concretos de linguagem está em sua adaptação da "Teoria das Semioses Criativas e Orientadas" de Nöth (1995).

O processo de interpretação dos signos é, sobretudo, um processo semiótico. Assim, esta atividade mental de percepção e de interpretação de signos depende do substrato teórico-metodológico da ciência Semiótica, a Ciência Geral dos Signos.

O objeto da Semiótica - A Ciência Geral dos Signos - é a semiose, definida como a ação e atividade dos signos. A semiose é o processo de interpretação, o efeito dos signos na mente dos intérpretes. A semiose é o termo que define a ação e a atividade dos signos. Segundo Correia (2012, p. 94),

na geração dos significados na mente do intérprete, a semiose é o processo transformador dos fenômenos existentes no universo real da experiência, que, através da relação dialética entre mente interpretadora e signo, transforma o fenômeno-experiência em veículo portador de significação: o signo. 
Assim, o avanço analítico do uso do conceito de semiose neste trabalho está na ênfase dada ao sujeito cognitivo no processo de geração das semioses. Nesta perspectiva, as semioses podem ser analisadas e observadas a partir das situações reais de significação. Os diversos signos que são encontrados nas telas que veiculam as hipermídias reclamam por mentes interpretadoras para interpretá-los. Os usuários interpretam estes signos e traçam seus caminhos de interpretação nas vias virtuais do ciberespaço. Acreditamos que as escolhas das notícias em plataformas digitais realizadas pelos profissionais de jornalismos seguem uma lógica que depende das orientações sígnicas.

Segundo Correia (2012, p. 112) todo processo de interpretação de signos depende da procura, ou seja, depende do processo de leitura-interpretação de signos capazes de auxiliar os complexos caminhos da representação. Isto se torna mais evidente quando observamos a complexidade de signos de diferentes naturezas que compõem o ciberespaço. Porém, os usuários no ciberespaço não encontram apenas signos de orientação; ao contrário, encontram, constantemente, signos de desorientação no decorrer de sua navegação pelas infovias dos sites, portais e etc. Duas definições são importantes para o entendimento dos processos de interpretação dos signos: o conceito de semiose criativa e de semiose orientada.

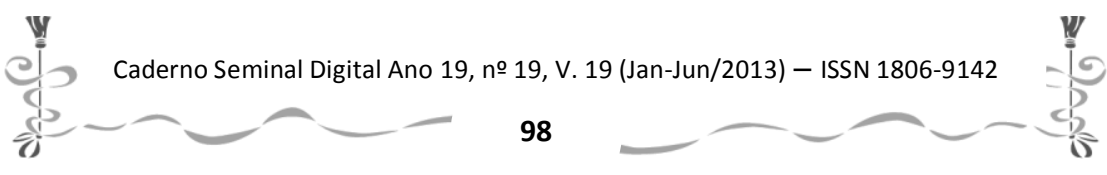


Nöth (1995, p. 107) propõe o conceito de "signo orientador", enquanto um signo interpretado "com sucesso com base em um código válido, e o resultado dessa semiose está de acordo com as expectativas do intérprete"; já o processo de desorientação (no processo de interpretação dos signos) foi caracterizado por Nöth (1995, p. 108) como "semiose incompleta e transformada", de forma que o "intérprete desorienta-se porque um dos correlatos do signo não pode ser identificado". Para Nöth, estas transformações sígnicas nos processos de interpretação são enganosas ou criativas.

Seguindo as perspectivas de Correia (2012) e Nöth (1995), os conceitos de "semiose criativa" e de "semiose transformada" servem para a observação das formas como os usuários das plataformas digitais, como intérpretes de plataformas essencialmente semióticas (devido à natureza simbólica e à diversidade de signos) interpretam e escolhem as notícias que deverão ser trabalhadas e posteriormente veiculadas.

Assim, podemos perceber que a interpretação das linguagens depende das relações estabelecidas entre os receptores da informação e os signos, entre as mentes interpretadoras e a experiência. Este processo de tradução da experiência em signo, em cognição, em linguagem, é chamado na Semiótica de "semiose". No caso da produção jornalística, o profissional possui a experiência para detectar em meio a

Caderno Seminal Digital Ano 19, no 19, V. 19 (Jan-Jun/2013) - ISSN 1806-9142
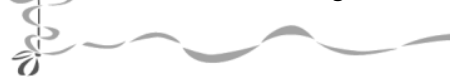
gama de informações postadas nas RCl's, em plataformas digitais portáteis, aquela que poderá servir como uma pauta plausível para publicação. O que parece rotineiro para o leigo na área de Jornalismo, salta aos olhos do jornalista capacitado para a apuração de notícias como material merecedor de publicação. Acreditamos que este processo de seleção das notícias pode ser explicado a partir das teorias das Semioses Orientadas e Criativas desenvolvidas por Nöth (1995).

\section{3- O JORNALISMO DIGITAL E OS NOVOS NÍVEIS DE PRODUÇÃO DA INFORMAÇÃO}

Na obra "Jornalismo Digital em Base de Dados (JDBD): Um paradigma para produtos jornalísticos digitais dinâmicos", Barbosa (2007) fala sobre o surgimento do Jornalismo Digital em Banco de Dados, ocorrido entre as terceira e quarta gerações do desenvolvimento do Webjornalismo. Barbosa (2007) discute, no mesmo trabalho, as dezoito funções do Jornalismo em um site estruturado em uma base de dados: (1) Indexar e classificar as peças informativas e os objetos multimídia; (2) integrar os processos de apuração, composição e edição dos conteúdos; (3) conformar padrões novos para a construção das peças informativas; (4) agilizar a produção de conteúdos; (5) propiciar categorias diferenciadas para a classificação externa dos conteúdos; (6) estocar o material produzido e preservar os arquivos; (7) permitir usos e concepções diferenciadas para o material de arquivo; (8) garantir a flexibilidade combinatória entre os conteúdos; (9)

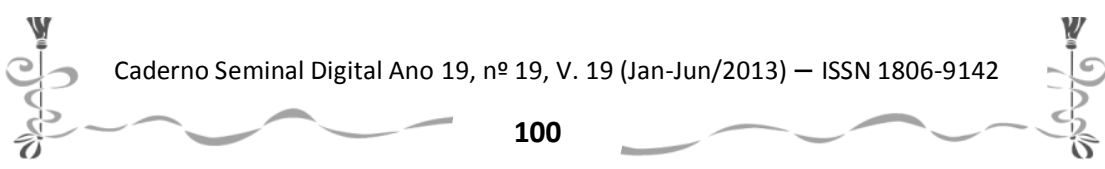


gerar resumos de notícias estruturadas e/ou matérias de modo automatizado; (10) armazenar anotações semânticas sobre os conteúdos inseridos; (11) mineração de dados (data mining); (12) ordenar e qualificar os colaboradores; (13) orientar e apoiar o processo de apuração, coleta, e contextualização dos conteúdos; (14) regular o sistema de categorização de fontes jornalísticas; (15) sistematizar a identificação da redação; (16) cartografar o perfil dos usuários; (17) transmitir e gerar informação para dispositivos móveis e (18) implementar publicidade dirigida.

Estas funções serão utilizadas na análise dos dados que será apresentada no próximo subitem.

\section{1 - Análise do processo de produção jornalística na hipermídia: o Portal Amazônia.}

Como primeiro procedimento de análise, as teorias desenvolvidas por Barbosa, Machado e Pereira (2011, p. 167182) foram selecionadas por trazerem subsídios para uma varredura de funções específicas que dizem respeito ao webjornalismo. Por questões metodológicas, e tendo em vista à aplicação da teoria estudada, decidimos neste momento do desenvolvimento da pesquisa analisar o Portal Amazônia, com o objetivo de observar, principalmente, as questões relacionadas com a interatividade entre o leitor e o processo de produção jornalística em hipermídia. O cibermeio foi escolhido por fazer parte de um conglomerado de produtos de Jornalismo, possibilitando a integração da informação entre as

Caderno Seminal Digital Ano 19, no 19, V. 19 (Jan-Jun/2013) - ISSN 1806-9142
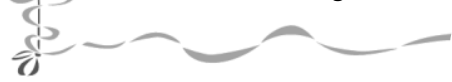

101

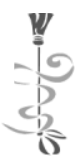


Caderno Seminal Digital

(1)

publicações, além de analisar o nível de importância de um portal online em uma empresa que conta também com veículos televisivo e radiofônico.

Além da integração com outros meios de comunicação, o histórico do cibermeio Portal Amazônia nos chamou a atenção por estar atuante no mercado desde 2001, durante a primeira fase do webjornalismo, definida como transpositiva, na obra "Características e implicações do Jornalismo na Web" de Mielniczuk (2001). Segundo a autora, esta fase refere-se ao período em que um cibermeio apenas copiava matérias publicadas por outros meios pertencentes a uma mesma empresa de comunicação, além do uso quase que inexistente de multimídia ou interatividade com leitores. O cibermeio aqui analisado passou pela segunda fase - chama de metáfora, com a inclusão de hiperlinks e estreitamento da relação entre jornalistas e leitores.

Atualmente, o cibermeio está registrado em redes sociais, o que possibilita contato em tempo real com leitores. Além disso, outra característica coloca o portal na terceira geração do webjornalismo: multimidialidade. O cibermeio analisado apresenta em sua página online fotos e vídeos que enriquecem a informação publicada. Com a utilização de mídias integradas ao texto, o cibermeio encaixa-se perfeitamente para a avaliação da utilização de banco de dados durante as fases de produção da informação.

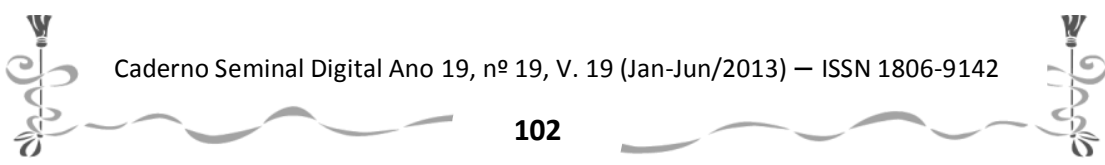


Caderno Seminal Digital

A metodologia proposta por Barbosa, Machado e Pereira (2011, p. 167-182) foi utilizada como recurso metodológico para a análise do Portal Amazônia. Assim o processo de análise foi dividido da seguinte forma:

\begin{tabular}{|l|l|}
\hline \multicolumn{1}{|c|}{ Item } & \multicolumn{1}{|c|}{ Definição } \\
\hline Interatividade do leitor & $\begin{array}{l}\text { Avalia a possível existência de um cadastro no } \\
\text { site para que ele possa ler, fazer comentários, } \\
\text { participar de enquetes e compartilhar o o } \\
\text { conteúdo em redes sociais ou via e-mail. }\end{array}$ \\
\hline $\begin{array}{l}\text { Utilização da Base de } \\
\text { Dados nas etapas de } \\
\text { produção }\end{array}$ & $\begin{array}{l}\text { Averigua em que etapas da produção jornalística } \\
\text { (apuração, produção, busca e circulação) o leitor } \\
\text { pode participar. }\end{array}$ \\
\hline Intranet & $\begin{array}{l}\text { É uma rede local de uma empresa jornalística que } \\
\text { funciona usando o mesmo protocolo da Internet. } \\
\text { Nela, está interligada a redação do site, e esta } \\
\text { intranet pode estar estruturada em uma base de } \\
\text { dados para o melhor gerenciamento das } \\
\text { informaçães produzidas e do fluxo informativo } \\
\text { em um website. }\end{array}$ \\
\hline Produção e circulação & $\begin{array}{l}\text { Este item busca saber se a produção e publicação } \\
\text { de matérias jornalísticas são feitas por meio de } \\
\text { uma única base de dados, ou se recorre a mais de } \\
\text { uma plataforma para as diferentes etapas. }\end{array}$ \\
\hline
\end{tabular}

Caderno Seminal Digital Ano 19, no 19, V. 19 (Jan-Jun/2013) - ISSN 1806-9142 
Caderno Seminal Digital

\begin{tabular}{|c|c|}
\hline Item & Definição \\
\hline Serviço Terceirizado & $\begin{array}{l}\text { Refere-se à origem da base de dados. O site } \\
\text { contratou profissionais especializados para } \\
\text { produção e manutenção da base de dados ou } \\
\text { recorreu a uma empresa terceirizada para o } \\
\text { serviço. }\end{array}$ \\
\hline Software Livre & $\begin{array}{l}\text { Deve-se saber se o site está hospedado em uma } \\
\text { host gratuita e de livre personalização. Na } \\
\text { maioria dos casos, sites com mais recursos } \\
\text { interativos precisam pagar pela utilização da } \\
\text { plataforma. }\end{array}$ \\
\hline Etapas de Produção & $\begin{array}{l}\text { Saber quais etapas da produção jornalística } \\
\text { (apuração, produção, circulação e consumo) } \\
\text { estão englobadas na base de dados do website. }\end{array}$ \\
\hline $\begin{array}{l}\text { Convergência } \\
\text { Jornalística }\end{array}$ & $\begin{array}{l}\text { Aqui, se está referindo às quatro áreas de } \\
\text { abrangência da convergência jornalística. Pode } \\
\text { ocorrer que a plataforma utilizada por um } \\
\text { cibermeio apenas permita a distribuição entre } \\
\text { meios distintos, isto é, multiplataforma (web, } \\
\text { impresso, celular, Twitter, etc.), por exemplo. Ou, } \\
\text { pode acontecer, dos profissionais trabalharem } \\
\text { usando plataformas distintas (uma para o } \\
\text { impresso, outra para o website). Quanto mais } \\
\text { tipos estiverem integrados, mais robusta será a } \\
\text { plataforma, o que será um indicativo também do } \\
\text { nível de integração existente na redação de um } \\
\text { cibermeio. }\end{array}$ \\
\hline
\end{tabular}

Caderno Seminal Digital Ano 19, no 19, V. 19 (Jan-Jun/2013) - ISSN 1806-9142 


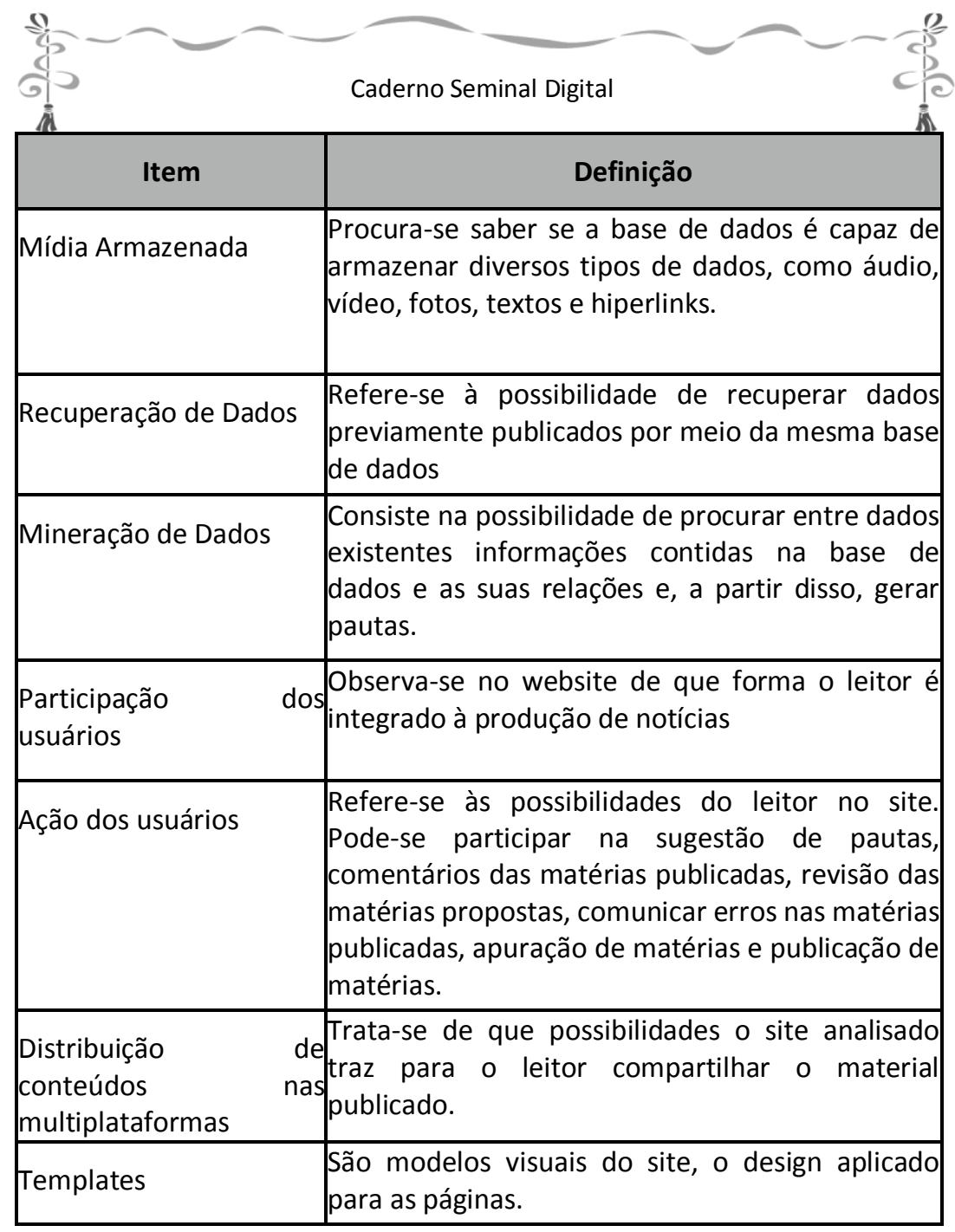

Caderno Seminal Digital Ano 19, no 19, V. 19 (Jan-Jun/2013) - ISSN 1806-9142 
Caderno Seminal Digital

\begin{tabular}{|l|l|}
\hline \multicolumn{1}{|c|}{ Item } & \multicolumn{1}{|c|}{ Definição } \\
\hline Documentação & $\begin{array}{l}\text { Procura-se saber se o site utiliza algum padrão } \\
\text { para a documentação das informações da base de } \\
\text { dados. }\end{array}$ \\
\hline $\begin{array}{l}\text { Geração de conteúdo } \\
\text { automatizada }\end{array}$ & $\begin{array}{l}\text { Refere-se aos alertas noticiosos que os jornalistas } \\
\text { possam receber a partir do sistema de apuração } \\
\text { interligado à intranet e ao sistema de de } \\
\text { gerenciamento de conteúdo ou sistema editorial }\end{array}$ \\
\hline Cadastro de anunciantes & $\begin{array}{l}\text { lrata-se de saber como acontece a escolha de } \\
\text { anunciantes de publicidade dentro do site }\end{array}$ \\
\hline $\begin{array}{l}\text { Informações } \\
\text { relacionadas }\end{array}$ & $\begin{array}{l}\text { Trata-se de saber qual sistema o site utiliza para a } \\
\text { base de dados e como elas se relacionam dentro } \\
\text { do banco de dados }\end{array}$ \\
\hline $\begin{array}{l}\text { Recuperação } \\
\text { memória }\end{array}$ & $\begin{array}{l}\text { dqui, refere-se aos arquivos internos e de como } \\
\text { jornalistas têm acesso a esse material } \\
\text { documental, de memória, para compor os } \\
\text { conteúdos. Em muitos sites, a recuperação deste } \\
\text { material se dá por meio de base de dados } \\
\text { integrada à intranet e ao sistema de } \\
\text { gerenciamento de conteúdos ou sistema } \\
\text { editorial. }\end{array}$ \\
\hline Tabela 1-Procedimentos de Análise \\
\hline
\end{tabular}

No que diz respeito à interatividade do leitor, durante a análise do site foi possível perceber que não é necessário cadastro para ter acesso às matérias publicadas, tampouco para comentar ou compartilhar a página na Internet. No caso

Caderno Seminal Digital Ano 19, no 19, V. 19 (Jan-Jun/2013) - ISSN 1806-9142 
Caderno Seminal Digital

â

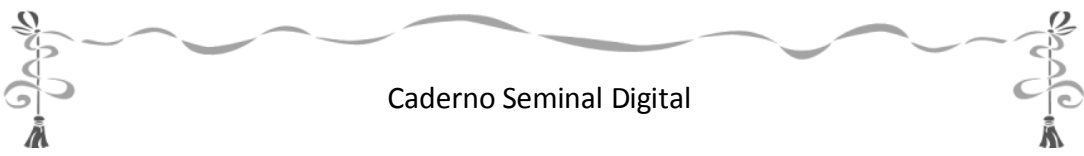

de postar um comentário em determinada matéria, o site solicita apenas o nome do internauta, além do e-mail do próprio. O comentário, porém, não é publicado imediatamente, dependendo de uma aprovação do editor. Já no caso de compartilhamento do material na Internet, o leitor deve fazer login em uma das redes sociais em uma página redirecionada pelo próprio portal, podendo, desta forma, realizar comentários e compartilhamentos por meio de plataformas digitais portáteis, como smartphones e tabletes.

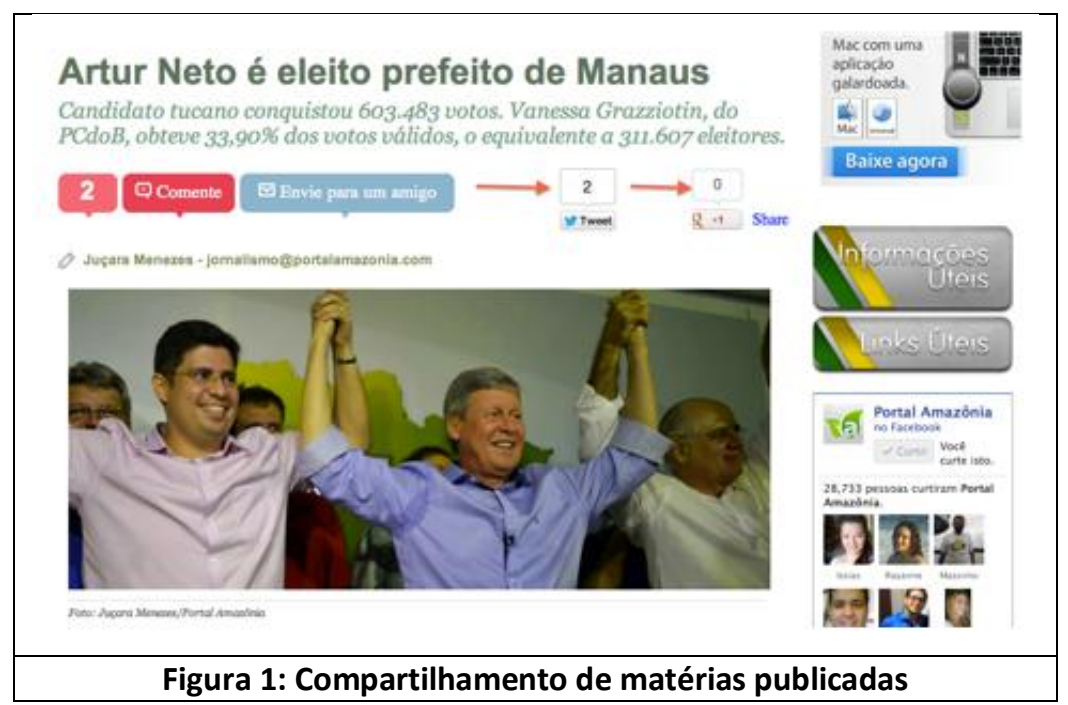

Sobre a utilização de base de dados nas etapas de produção, o site utiliza o $S G C$ desde a apuração (busca de informações publicadas em matérias anteriores que possam auxiliar em uma matéria em estágio de produção),

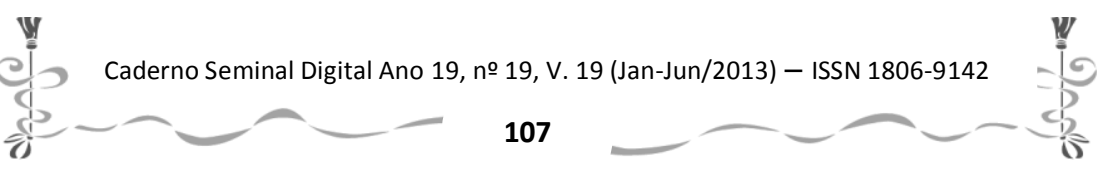


Aิ

recuperação e memória (rápida e fácil identificação de material armazenado). O cibermeio utiliza a Intranet estruturada entre todos os veículos de comunicação da empresa proprietária do site, que possui um canal televisivo e uma estação de rádio. Desta forma, um repórter da TV pode encaminhar uma mensagem com informações sobre um assunto para todos os outros meios para apuração conjunta. A empresa utiliza o software EasyNews, desenvolvido pela empresa de mesmo nome, porém não possui adaptação para plataformas portáteis, limitando-o ao trabalho in office.

Sobre a produção e circulação, serviço terceirizado e software livre, a base de dados utilizada para a publicação de informações é a mesma utilizada como base de dados para arquivar matérias anteriores, assim como multimídias publicadas nas mesmas. O cibermeio paga um host para a empresa Wordpress, especializada na montagem de blogs e sites.

No que concerne às etapas de produção, o Banco de Dados utilizado pelo cibermeio avaliado encontra-se: durante a apuração (caso seja necessário obter informações prévias sobre um assunto, o jornalista pode buscar na base de dados matérias anteriores para consulta) e produção (o jornalista utiliza a base de dados para escrever o texto, inserir fotos, vídeos e hiperlinks).

Sobre a convergência jornalística, mídia armazenada e recuperação de dados, cabe ressaltar que o banco de dados

Caderno Seminal Digital Ano 19, no 19, V. 19 (Jan-Jun/2013) - ISSN 1806-9142
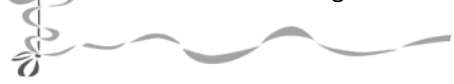

108

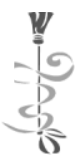


EasyNews permite a convergência de conteúdos do cibermeio com os outros produtos emitidos pela empresa, além de permitir que seus funcionários façam entradas ao vivo no canal televisivo para divulgação do material produzido online. O cibermeio é capaz de salvar e recuperar outras mídias, além do texto em sua base de dados, como áudios (no formato .mp3), vídeo (postados via hiperlink ou em formatos variados) e fotos (no formato .jpeg).

A mineração de dados consiste na busca de informações publicadas anteriormente para o enriquecimento do material ainda na etapa de produção. Este artifício é possibilitado por meio de tags. Estas "etiquetas" são palavraschave que são publicadas juntamente à matéria para categorização do assunto discutido. Elas permitem que diversas matérias que tratam de um mesmo assunto sejam associadas entre si. A manutenção destas etiquetas é feita, na maioria das vezes, nos computadores dentro da própria redação, mas há a possibilidade de ser realizada, também, em smartphones e tabletes com acesso à Internet.

Uma questão fundamental para todas as pesquisas e estudos sobre a produção da informação no ciberespaço é a participação dos usuários e, também, a ação dos usuários. $A$ plataforma de produção e gestão de conteúdos do cibermeio Portal Amazônia permite aos usuários cadastrados a interação em etapas como a apuração, a circulação e o consumo da notícia; para esta última etapa não se faz necessário um

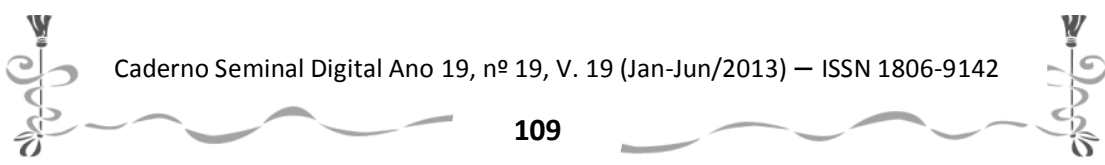


cadastro prévio. Comentários nas matérias publicadas, revisões e apurações de matérias propostas e, também, a divulgação de matérias através das redes sociais só são permitidas apenas aos usuários cadastrados.

Sobre a distribuição de conteúdos nas multiplataformas, o cibermeio Portal Amazônia permite aos usuários cadastrados a divulgação de seu conteúdo produzido em diversas multiplataformas, como RSS, Twitter, Portal e Redes Sociais.

Templates, ou 'modelos de documentos', são documentos sem conteúdo, com apenas a apresentação visual e instruções sobre onde e qual tipo de conteúdo deve entrar a cada parcela da apresentação. A plataforma de produção de conteúdos do Portal Amazônia não possui uma base de dados de templates com diferentes modelos de narrativa que possam ser utilizados pelos jornalistas no processo de produção. O cibermeio também não conta com uma norma padrão para a documentação do conteúdo produzido.

No cibermeio há seções ou editorias do menu informativo cujo conteúdo é gerado de modo automatizado. É cada vez mais comum tal prática na composição do conteúdo oferecido pelos cibermeios; ou seja, a partir das informações contidas e estruturadas nas bases de dados, e segundo alguns parâmetros definidos para os robôs efetuarem buscas, é possível exibir os conteúdos conforme categorias previamente definidas. No caso do cibermeio Portal Amazônia

Caderno Seminal Digital Ano 19, no 19, V. 19 (Jan-Jun/2013) - ISSN 1806-9142 
Caderno Seminal Digital

î.

tem-se como exemplo as seções 'Amazônia de A a Z' e 'Mais Lidas'.

Sobre o cadastro de anunciantes, informações relacionadas e recuperação da memória, vale ressaltar que boa parte dos sistemas de gerenciamento de conteúdos, ou sistemas editoriais, já tem integrado o módulo de publicidade para a melhor gestão dos anunciantes do cibermeio, principalmente no contexto da convergência e das redações integradas. Porém, isto não acontece com o cibermeio analisado. O cibermeio Portal Amazônia utiliza o sistema de base de dados EasyNews no processo de relacionamento de informações atuais e salvas na memória, bem como na recuperação das informações salvas na memória, relacionando-as automaticamente.

\section{4- CONSIDERAÇÕES FINAIS}

Ao final de nossas análises ficou evidente que a utilização de um sistema de banco de dados em um cibermeio é, como destacado por Moreno (2009, p.119), "fator primordial para a construção de um cibermeio". Este objeto de estudo é o alicerce no qual todos os processos de produção da informação estão sustentados e possibilita a criação de um ciclo na prática jornalística, desde a proposição de pautas por meio da Intranet, a comunicação a outros veículos de comunicação sobre um acontecimento, passando pela produção (utilizando a base de dados como plataforma para

Caderno Seminal Digital Ano 19, no 19, V. 19 (Jan-Jun/2013) - ISSN 1806-9142

111

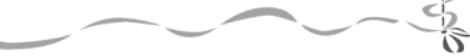


publicação das matérias online), até o armazenamento e mineração deste conteúdo para futura consulta, o que levará novamente à sugestão de pautas.

Esta pesquisa possibilitou, também, a compreensão do avanço do webjornalismo na região amazônica. Há dez anos o cibermeio analisado apenas copiava o conteúdo publicado pela TV da mesma empresa e por assessorias de comunicação; hoje, além de produzir seu próprio conteúdo, ele investe em mídias online para enriquecer o valor informacional; mídias cuja natureza híbrida permite a mistura de signos e linguagens de diferentes naturezas, misturando informações e gerando novos sentidos. Todo este processo propicia a emergência de novos códigos e reclama por novas formas de produção e de recepção das notícias. Os caminhos da produção e da recepção da informação nas infovias do ciberespaço se apresentam como uma rede complexa, cujo funcionamento só pode ser entendido pelas complexas relações que estabelece com as mentes que percorrem os nós de conexão, buscando os significados, os sentidos e a comunicação.

\section{REFERÊNCIAS}

BARBOSA, Suzana. Modelo JDBD e o ciberjornalismo de quarta geração. 2008. Disponível em:

\section{http://www.facom.ufba.br/jol/pdf/2008}

BARBOSA, Suzana; MACHADO, Elias; PEREIRA, José. Ferramenta para Análise de Bases de Dados em Cibermeios. Covilhã: LabCom. 2011.

Caderno Seminal Digital Ano 19, no 19, V. 19 (Jan-Jun/2013) - ISSN 1806-9142 
Caderno Seminal Digital

î.

CANAVILHAS, João Messias. Webjornalismo: considerações gerais sobre jornalismo na web. Disponível em:

http://www.bocc.ubi.pt/pag/ texto.php3?htm/2=canavilhas-joaowebjornal.html. Acesso em: 23.03.2012.

CASTELLS, Manuel. The rise of network society. Oxford and Malden Mass: Blackwell, 1996.

CORREIA, Claudio Manoel de Carvalho. "Competência Semiótica, percepção e desenvolvimento das interpretações". In: SIMÕES, Darcilia (Org.) Língua portuguesa e ensino: reflexões e propostas sobre a prática pedagógica. São Paulo: Factash, 2012.

DELEUZE, Gilles e GUATTARI, Félix. Mil platôs: capitalismo e esquizofrenia. Rio de Janeiro: Editora 34, 1980. v.5.

KASTRUP, Virgínia. A invenção do mundo e de si: uma introdução do tempo e do coletivo no estudo da cognição. 1997. Tese de doutorado - Pontifícia Universidade Católica de São Paulo, 1997.

LASSWELL, H.D. "The structure and function of communication in society". In: SCHRAMM, W. The process and effects of Mass Communication. Urbana: University of Illinois Press, 1957.

MIELNICZUK, Luciana. "Características e implicações do jornalismo na Web". In: II CONGRESSO DA ASSOCIAÇÃO PORTUGUESA DE COMUNICAÇÃO, 2001, Lisboa.

MORENO, Plácido. Reinventando el periódico: una estrategia para la supervivencia de la prensa diaria. Madrid: Euroeditions, 2009.

NÖTH, Winfried. Panorama da semiótica: de Plantão a Peirce. São Paulo: Annablume, 1995.

Caderno Seminal Digital Ano 19, no 19, V. 19 (Jan-Jun/2013) - ISSN 1806-9142

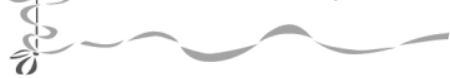

113

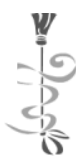


Caderno Seminal Digital

离

\section{Caderno Seminal Digital}

SANTAELLA, Lucia; LEMOS, Renata. Redes sociais digitais: a cognição conectiva do Twitter. São Paulo: Paulus, 2010.

WIENER, Norbert. El hombre y las maquinas. Venezuela: Monte Ávila, 1974.

Caderno Seminal Digital Ano 19, no 19, V. 19 (Jan-Jun/2013) - ISSN 1806-9142 